\title{
A method for the inline measurement of milk gel firmness using an optical sensor
}

\author{
O. Arango* $\dagger^{1}$ and M. Castillo* \\ ${ }^{*}$ Centre d'Innovació, Recerca i Transferència en Tecnologia dels Aliments (CIRTTA), Xarxa de referència en tecnologia dels aliments \\ de la Generalitat de Catalunia (XaRTA), TECNIO-CERPTA, Departament de Ciència Animal i dels Aliments, Facultat de Veterinària, \\ Universitat Autònoma de Barcelona, 08193 Bellaterra, Spain \\ †Facultad de Ingeniería Agroindustrial, Universidad de Nariño, Ciudad Universitaria Torobajo, Pasto, Nariño PC 52001, Colombia
}

\begin{abstract}
At present, selection of cutting time during cheesemaking is made based on subjective methods, which has effects on product homogeneity and has prevented complete automation of cheesemaking. In this work, a new method for inline monitoring of curd firmness is presented. The method consisted of developing a model that correlates the backscatter ratio of near infrared light during milk coagulation with the rheological storage modulus. The model was developed through a factorial design with 2 factors: protein concentration (3.4 and $5.1 \%)$ and coagulation temperature $\left(30\right.$ and $\left.40^{\circ} \mathrm{C}\right)$. Each treatment was replicated 3 times; the model was calibrated with the first replicate and validated using the remaining 2 replicates. The coagulation process was simultaneously monitored using an optical sensor and small-amplitude oscillatory rheology. The model was calibrated and successfully validated at the different protein concentrations and coagulation temperatures studied, predicting the evolution of storage modulus during milk coagulation with coefficient of determination values $>0.998$ and standard error of prediction values $<3.4 \mathrm{~Pa}$. The results demonstrated that the proposed method allows inline monitoring of curd firming in cheesemaking and cutting the curd at a proper firmness to each type of cheese.
\end{abstract}

Key words: gel firmness, milk coagulation, cheese making, cutting time

\section{INTRODUCTION}

Determining gel firmness values from inline optical measurements has long been a goal for milk gels, because the monitoring and control of its evolution over time can bring many benefits in the manufacturing of

Received July 29, 2017.

Accepted December 1, 2017.

${ }^{1}$ Corresponding author: oscar.arango@udenar.edu.co different dairy products, particularly cheese. In cheese manufacturing, cutting time (CT) selection depends on the type of cheese being made. Early cutting enables much rearrangement to occur after cutting, increasing syneresis and reducing cheese moisture content, whereas late cutting has opposite effects (Fagan et al., 2007). Therefore, cutting should be initiated at a consistent curd firmness that is optimized for the type of cheese being made.

In most cheese plants, gel is usually cut after a predetermined reaction time or upon the operator's visual judgment of textural properties. The first method is questionable because of factors that affect the coagulation process, such as milk composition, could vary the optimum CT. In the second method the decision depends on the experience of a cheesemaker, but it is not objective (Castillo, 2006a).

Numerous devices have been developed to assess the coagulation of milk and determine optimal coagulum CT (Kübarsepp et al., 2005; Castillo, 2006a; Klandar et al., 2007). Among these are the Formagraph (Foss Electric A/S, Hillerød, Denmark), based on the drag force technique (Dal Zotto et al., 2008; Bittante et al., 2012); the low-amplitude dynamic oscillatory rheometer (Hemar et al., 2004; Frederiksen et al., 2011; Jakob et al., 2011); ultrasonic sensing devices (Cosgrove, 2000; Taifi et al., 2006; Koc and Ozer, 2008); and the hot wire probe (Hori, 1985; Passos et al., 1999; O'Callaghan et al., 2001). However, several of these methods are intrusive, destructive, do not work inline, or are not practical for in-plant implementation; for more than 6 decades, the industry has lacked an efficient and reliable, nondestructive, easy-to-clean, and sanitary inline monitoring curd-firming sensor, which is a serious hindrance to complete cheesemaking automation.

Study of network formation has often been achieved using light scattering. In milk and, especially, in the visible and near infrared ranges, light scattering predominates over absorption. Light scattering changes during coagulation are directly related to the rate of aggregation and curd firming if total casein concentra- 
tion does not vary during the measurements (Castillo, 2006a).

According to Payne et al. (1993), the logarithmic period observed in the diffuse reflectance profile of coagulating milk appeared to follow the same pattern as the rheological changes. The optic inline sensor CoAguLite, developed by Payne et al. (1990), measures near infrared light backscatter (LB) and has been successfully applied to determine cutting time of cow milk (Payne et al., 1993), goat milk (Castillo et al., 2000), sheep milk (Nicolau et al., 2011), low-fat milk with inulin (Arango et al., 2013), and milk mixtures (Abdelgawad et al., 2014). This technique is currently commercially available for inline monitoring of cheesemaking, especially in the United States.

One reason for further modeling the coagulation process is to have an objective way to determine a measure of the gel firmness at cutting, as this is thought to be important for controlling yield and cheese moisture content. The objective of our work was to develop and evaluate a method for the inline measurement of milk gels firmness using an optical sensor.

\section{MATERIALS AND METHODS}

\section{Experimental Design}

The method for prediction of storage modulus $\left(\mathbf{G}^{\prime}\right)$ values (curd firming) during milk coagulation, using data from an optical sensor, was evaluated through a factorial design replicate 3 times with 2 factors: coagulation temperature $\left(30\right.$ and $\left.40^{\circ} \mathrm{C}\right)$ and milk protein concentration (3.4 and 5.1\%). In the cheese industry, coagulation temperature is kept constant but may be different depending on the type of cheese being made. On the other hand, milk protein content varies naturally; in some cases protein concentrates may be added to increase yield. Accordingly, the factor levels were selected with the aim of evaluating the proposed method in a broad spectrum of coagulation conditions. In addition, temperature and protein concentration are 2 of the most relevant factors known to affect the curd $\mathrm{G}^{\prime}$ value (Castillo et al., 2003a). The coagulation process was simultaneously monitored using an inline LB sensor and small-amplitude oscillatory rheometry. For each treatment, the first replication was used to calibrate the model and the other 2 were used to validate the model.

\section{Near-Infrared LB Sensor}

The laboratory equipment with a near-infrared LB sensor used to carry out our study is shown in Figure 1.
A detailed description has been presented in Castillo et al. (2006b) and Tabayehnejad et al. (2012).

The laboratory equipment had 2 identical vats (98$\mathrm{mL}$ capacity), allowing simultaneous coagulation tests. Averaging the measurements improved the accurate of the optical parameters. In the sensor, light from a lightemitting diode was transferred to the milk through a fiber, and the light backscattered from the milk was transmitted through an adjacent fiber to an optical detector. Sample temperature in the 2 milk sample vats was controlled using a circulating water bath (Lauda RM 20, Brinkmann Instruments Inc., Westbury, NY) and was measured with a precision thermistor thermometer. A light backscatter ratio $(\boldsymbol{R})$ profile was calculated starting immediately after enzyme addition by dividing the voltage output from the detector by the average of the first 10 voltage data points collected, according to the procedure described by Castillo et al. (2000). Values of $R$ were collected every $6 \mathrm{~s}$, which allowed us to obtain an accurate profile showing the evolution of milk coagulation. The changes that occurred in the milk during coagulation were correlated with the signal changes derived from the optical sensor, and the $R$ value increased as aggregation and gel assembly proceeded.

\section{Rheological Monitoring of Milk Coagulation}

Small-amplitude oscillatory dynamic trials were carried out with a concentric-cylinders sensor (Z34 DIN) in a ThermoHaakeRS1 rheometer coupled to a ThermoHaake water bath (Thermo-Haake GmbH, Karlsruhe, Germany) for the precise control of temperature. The frequency and the strain were set up at $1 \mathrm{~Hz}$ and $3 \%$, respectively (Hallén et al., 2007). An aliquot of $40 \mathrm{~mL}$ of milk with enzyme was transferred to the cylinder of the rheometer that was prewarmed to the assay temperature. The sample surface was covered with a thin layer of vegetable oil to avoid evaporative cooling during the coagulation. The rheological parameters storage $\left(G^{\prime}\right)$ and viscous $\left(G^{\prime \prime}\right)$ moduli were collected around every $25 \mathrm{~s}$ up to a $\mathrm{G}^{\prime}$ of $60 \mathrm{~Pa}$, using Rheowin Job Manager Software (Thermo Fisher Scientific, Karlsruhe, Germany). Gelation time $\left(\boldsymbol{t}_{\mathrm{G}^{\prime} 1}\right)$ was defined as the time when the gels had a $\mathrm{G}^{\prime}$ of $1 \mathrm{~Pa}$.

\section{Procedure of the Tests}

Low-heat, spray-dried milk powder with $34 \%$ protein and $0.9 \%$ fat (Chr. Hansen, Barcelona, Spain) was reconstituted to prepare the milk for the tests. Skim milk powder was selected for the study because it had a constant composition that allowed minimizing the ex- 
perimental sources of variation. The milk powder was weighed according to the amount required to achieve the protein percentage of the test, and afterward diluted with demineralized water. This mixture was placed on a magnetic stirrer with a regulated heating plate at $43^{\circ} \mathrm{C}$ for 60 min to completely reconstitute the milk powder in distilled water. After stirring, the milk was placed for $60 \mathrm{~min}$ in a dark place at room temperature for complete rehydration of the casein micelles.

After $60 \mathrm{~min}$ of rehydration, $0.3 \mathrm{~mL}$ of calcium chloride solution $\left(525 \mathrm{~g} / \mathrm{L} \mathrm{CaCl}_{2} \cdot 2 \mathrm{H}_{2} \mathrm{O}\right.$; Panreac Quimica S.A., Montcada i Reixac, Barcelona, Spain) was added to enhance milk coagulation. The milk was left in a thermostatic bath previously tempered at the test temperature; once it reached the thermal equilibrium, 100 $\mu \mathrm{L} / \mathrm{kg}$ of enzyme was added (recombinant chymosin 100\% CHY-MAX extra; EC 3.4.23.4, isozyme B, 600 international milk clotting units/mL, Chr. Hansen) and the mixture was stirred thoroughly with a spatula for 20 s. Immediately, 2 aliquots of $\sim 80 \mathrm{~mL}$ were placed in the optical sensor vessels and the near infrared LB- monitoring software was started. Another aliquot of $\sim 40 \mathrm{~mL}$ was placed in the rheometer and the respective data acquisition software was launched. The contents of protein on reconstituted milk samples were determined by the Dumas (IDF, 2002) method to determine the accuracy of formulation to meet target levels set forth by the experimental design. Means and standard deviations for the 2 protein levels tested were $3.39 \pm 0.02 \%$ and $5.07 \pm 0.02 \%$.

\section{Statistical Analysis}

All data were processed and analyzed using SAS version 2009 (SAS Institute Inc., Cary, NC). The suitability of the developed model to predict $\mathrm{G}^{\prime}$ was evaluated through the coefficient of determination $\left(\mathrm{R}^{2}\right)$ and the standard error of prediction (SEP; square root of the sum of squared residuals/df), obtained using linear regressions. The practical utility of the models was determined by means of the range error ratio (RER), calculated by dividing the range values of $\mathrm{G}^{\prime}$ by the a)

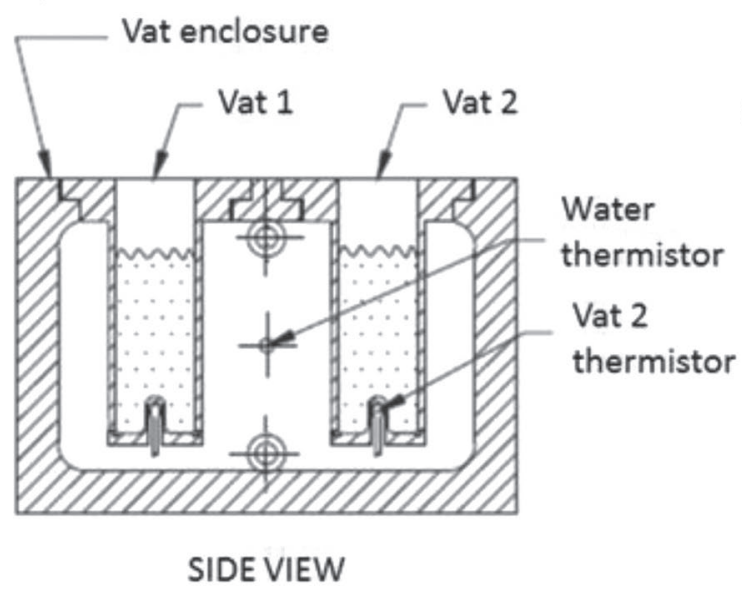

b)

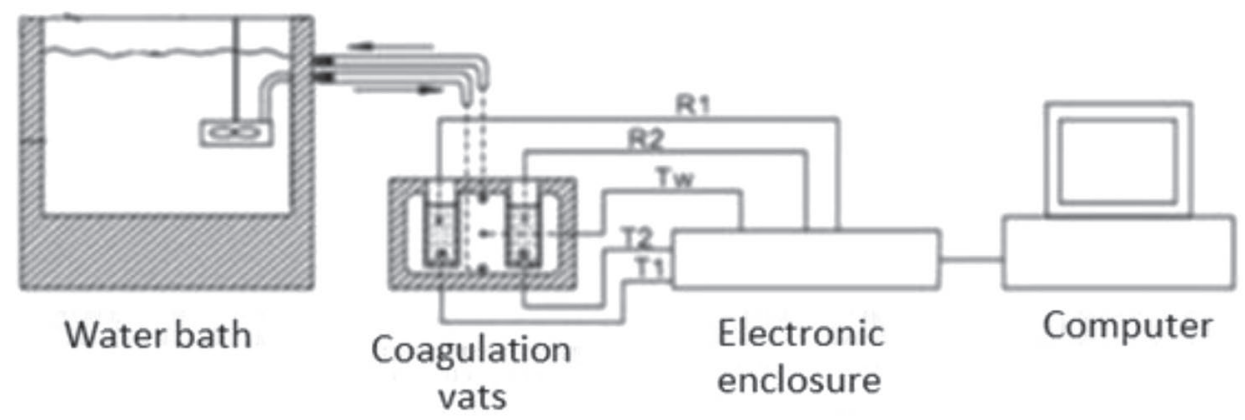

Figure 1. (a) Schematic of the apparatus used to measure near infrared light backscatter during milk coagulation and (b) schematic of the measurement system (adapted from Tabayehnejad et al., 2012). R1 = light backscatter sensor for vat 1; R2 = light backscatter sensor for vat $2 ; \mathrm{T} 1=$ thermistor for vat $1 ; \mathrm{T} 2=$ thermistor for vat 2. 
SEP in each treatment (Williams and Norris, 1987). As a typical CT is considered to correspond with a $\mathrm{G}^{\prime}$ between 20 to $35 \mathrm{~Pa}$ (Guinee et al., 1997; Everard et al., 2008), in our study the accuracy of the prediction of $\mathrm{G}^{\prime}=30 \mathrm{~Pa}$ was evaluated using these parameters mentioned previously.

\section{RESULTS AND DISCUSSION}

\section{Model to Predict G' Based on Near-Infrared Light Backscatter Ratio}

Many mathematical equations have been developed to predict the growth of gel firmness with time. Some models are based on empirical approaches (Scott Blair and Burnett, 1958) and others in kinetic mechanisms (Tuszynski, 1971; Douillard, 1973; Carlson et al., 1987; Clark and Amici, 2003). A comprehensive description of these methods with their pros and cons was presented by Horne and Banks (2004). Douillard (1973) proposed a model in which the rate of change of shear modulus with time followed first-order kinetics:

$$
\frac{\mathrm{dG}}{\mathrm{d} t^{*}}=\mathrm{k}\left(\mathrm{G}_{\infty}-\mathrm{G}\right) ; t^{*} \geq 0
$$

or

$$
t \geq t_{g}
$$

This equation can be integrated to give

$$
\mathrm{G}=\mathrm{G}_{\infty}\left[1-\mathrm{e}^{\left(-\mathrm{k} t^{*}\right)}\right]
$$

with the initial condition that $\mathrm{G}=0$ at $t=t_{g}$, where $t_{g}=$ coagulation time, $t^{*}=t-t_{g}, \mathrm{G}=$ shear modulus, $\mathrm{G}_{\infty}=$ the value of the shear modulus at $t=\infty$, and $\mathrm{k}$ is the rate constant for the process but essentially a fitting parameter. This equation has been several times in the history of studies on the rennet coagulation of milk. Tokita et al. (1982) fitted their curves to an $n$ th-order reaction equation and determined that the first-order form, the Douillard equation above, gave the best fit.

According to Castillo et al. (2003b), the curd assembly consists of 2 different reactions occurring simultaneously. The first reaction is the aggregation of casein micelles and was assumed to follow second-order kinetics. The second reaction is curd firming and was assumed to follow first-order kinetics. Assuming firstorder behavior for disappearance of crosslinking sites and a linear correlation between LB and the disappearance of crosslinking sites, the curd-firming process was described by the equation

$$
R-R_{0}=\left(R_{\infty}-R_{0}\right)\left(1-\mathrm{e}^{\mathrm{k}_{R} t}\right),
$$

where $R-R_{0}=$ the increase in the light scatter after $t_{2}$ min , resulting exclusively from gel firming reactions, where $t_{2 \min }$ is the time at which there is a minimum in the second derivative of a sigmoidal shaped portion of the light scattering ratio profile; $R_{0}=R$ value at $t_{2 \min }$; $R_{\infty}=$ asymptotic value at infinite time for the light scattering ratio; $\mathrm{k}_{R}=$ a first-order rate constant for gel firming reaction; and $t=$ time after $t_{2 \min }$. On the other hand, the Douillard model was adapted for the rate of change of storage modulus $\left(\mathrm{G}^{\prime}\right)$ with time as

$$
\begin{aligned}
& \mathrm{G}^{\prime}=\mathrm{G}_{0}^{\prime}+\left(\mathrm{G}_{\infty}^{\prime}-\mathrm{G}_{0}^{\prime}\right)\left(1-\mathrm{e}^{\mathrm{k}_{\mathrm{G}^{\prime}} t}\right), \\
& \mathrm{G}^{\prime}=\mathrm{G}_{\infty}^{\prime}+\mathrm{G}_{0}^{\prime} \mathrm{e}^{-\mathrm{k}_{\mathrm{G}^{\prime}} t}-\mathrm{G}_{\infty}^{\prime} \mathrm{e}^{-\mathrm{k}_{\mathrm{G}^{\prime}} t}, \\
& \mathrm{G}^{\prime}=\mathrm{G}_{\infty}^{\prime}+\left(\mathrm{G}_{0}^{\prime}-\mathrm{G}_{\infty}^{\prime}\right) \mathrm{e}^{-\mathrm{k}_{\mathrm{G}^{\prime}},},
\end{aligned}
$$

where $\mathrm{G}^{\prime}=$ the storage modulus at $t$ time; $\mathrm{G}_{\infty}^{\prime}=$ the value of the storage modulus at $t=\infty$; and $\mathrm{k}_{\mathrm{G}^{\prime}}=$ the rate constant for the process. Solving for the time in equation [3] and replacing into the equation [4], the following expression was obtained:

$$
\mathrm{G}^{\prime}=\mathrm{G}_{\infty}^{\prime}+\left(\mathrm{G}_{0}^{\prime}-\mathrm{G}_{\infty}^{\prime}\right)\left(\frac{R-R_{\infty}}{R_{0}-R_{\infty}}\right)^{\mathrm{k}_{\mathrm{G} R}}
$$

where $\mathrm{k}_{\mathrm{G} R}=\mathrm{k}_{\mathrm{G}} / \mathrm{k}_{R}$ is a constant representing the ratio between the rates of increase of $\mathrm{G}^{\prime}$ and $R$ values as a result of gel firming. The $\mathrm{k}_{\mathrm{G} R}$ can be obtained by a calibration process or by mathematically modeling its evolution with respect to specific working conditions. Equation [5] represents a mathematical model that does not include time and allows introducing $R$ data collected at real time into the model to calculate the value of the rheological variable $G^{\prime}$, representing the curd firmness.

\section{Fit and Validation of the Model}

As indicated in the Materials and Methods section, a factorial design with 2 factors, protein concentration (3.4 and 5.1\%) and coagulation temperature (30 and $40^{\circ} \mathrm{C}$ ), was used to develop the model. Each treatment was replicated 3 times; the model was calibrated with the first replicate and validated with the other 2 . The calibration process consisted of finding the values of model parameters $\left(\mathrm{G}_{0}^{\prime}, \mathrm{G}_{\infty}^{\prime}, R_{0}, R_{\infty}\right.$, and $\left.\mathrm{k}_{\mathrm{G} R}\right)$ that minimize the SEP value using Excel's Solver tool (Microsoft Corp., Redmond, WA). In the validation process, the goodness of the fit to a new data set obtained 


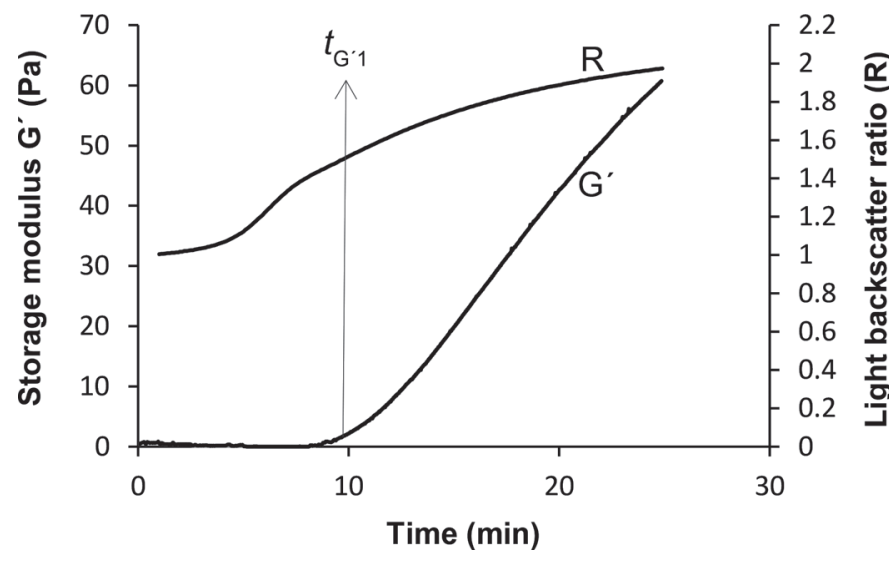

Figure 2. Evolution of the light backscatter ratio $(R)$ and the storage modulus $\left(\mathrm{G}^{\prime}\right)$ during coagulation at $30^{\circ} \mathrm{C}$ of milk samples with $3.4 \%$ protein. $\mathrm{t}_{\mathrm{G}^{\prime} 1}=$ gelation time.

in similar conditions (equal protein and temperature levels) was evaluated.

Figure 2 shows a typical $R$ profile obtained during milk coagulation and the simultaneous evolution of the $\mathrm{G}^{\prime}$. In this figure, it is possible to observe that from $t_{\mathrm{G}^{\prime} 1}$, $R$ increases as gel firming proceeds. Light backscatter ratio begins with a value of 1 and increases sigmoidally as milk coagulation proceeds, according with the increase in signal during coagulation. Castillo et al. (2003b) found that LB ratio profile during coagulation contains information regarding the enzymatic reaction rate, the rate of aggregation, and the rate of gel firming.

In Figure 3, the coagulation profiles of milk samples with 3.4 and $5.1 \%$ protein at 30 and $40^{\circ} \mathrm{C}$, monitored by means of oscillatory rheology and LB ratio, are compared. Temperature and protein increased milk coagulation rate evaluated using oscillatory rheology (Figure $3 a)$, with the effect of temperature stronger than that of protein, as generally accepted (van Hooydonk and van den Berg, 1988; Zoon et al., 1988; Guinee et al., 1997; Castillo et al., 2003a). Figure 3b shows that $R$ response was in accordance with the effect of these variables on the coagulation rate.

Using the LB ratio obtained with the optic sensor, it was possible to predict the curd firming by means of the proposed expression (equation [5]). Test predictions were carried out starting from the point where the increase in $\mathrm{G}^{\prime}$ was almost linear, that is when firming was around $5 \mathrm{~Pa}$. Table 1 shows the statistical parameters used to evaluate the developed model.

The model was calibrated with the first replication of each treatment, obtaining coefficient of determination values higher that 0.998 and SEP values between 0.39 and $1.40 \mathrm{~Pa}$. For each treatment, the model was successfully validated using the second and third replications, obtaining $\mathrm{R}^{2}>0.998$ and SEP between 0.21 and $3.41 \mathrm{~Pa}$. The parameter RER is useful to know the practical utility of a model, where $<3$ indicates little practical utility, between 3 and 10 indicates limited to good practical utility, and $>10$ indicates a high utility value (Fagan et al., 2009). In almost all cases, RER values obtained for model validation were $>10$, so the proposed model was found to be of high practical utility. In Table 1, measured and predicted values when the $\mathrm{G}^{\prime}$ reached $30 \mathrm{~Pa}$ are compared. The SEP obtained for prediction of $\mathrm{G}^{\prime}=30 \mathrm{~Pa}$ was only $1.7 \mathrm{~Pa}$ with a)

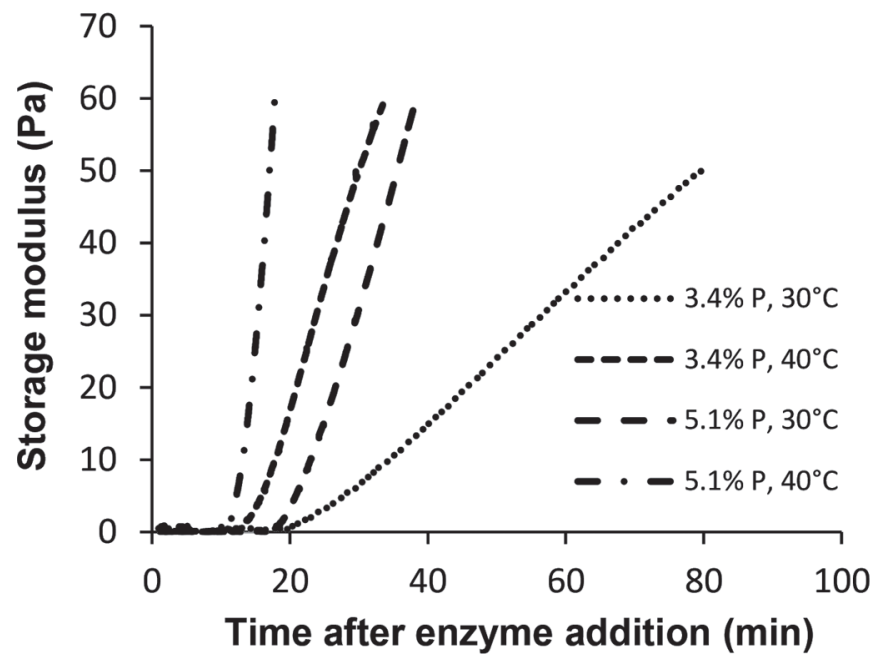

b)

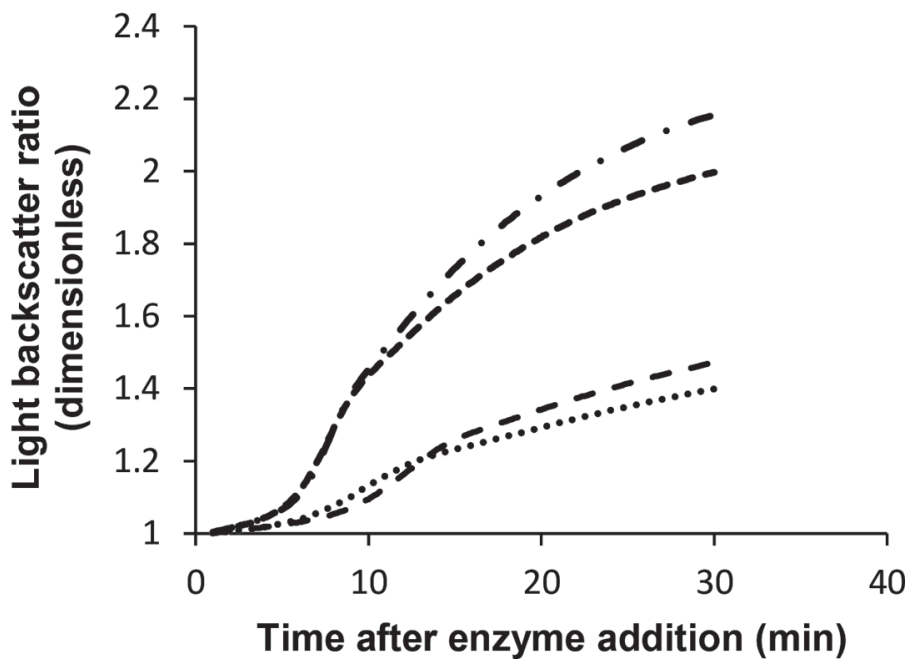

Figure 3. Coagulation profiles of milk samples with 3.4 and $5.1 \%$ protein at 30 and $40^{\circ} \mathrm{C}$, monitored by means of (a) oscillatory rheology and (b) light backscatter sensor. 
Table 1. Statistical parameters for fitting and validation of the proposal model to predict the storage modulus $\left(\mathrm{G}^{\prime}\right)^{1}$

\begin{tabular}{|c|c|c|c|c|c|c|}
\hline Test $^{2}$ & $\begin{array}{l}\text { Data } \\
\text { points }\end{array}$ & $\mathrm{R}^{2}$ & $\begin{array}{l}\text { SEP } \\
(\mathrm{Pa})\end{array}$ & RER & $\begin{array}{c}\text { Measured }^{3} \\
\mathrm{G}^{\prime}(\mathrm{Pa})\end{array}$ & $\begin{array}{c}\text { Predicted }^{3} \\
\mathrm{G}^{\prime}(\mathrm{Pa})\end{array}$ \\
\hline$(3.4,30)$ Rep1 & 316 & 0.9995 & 0.90 & 27.78 & 30.06 & 29.48 \\
\hline$(3.4,30)$ Rep2 & 298 & 0.9988 & 1.35 & 18.52 & 30.03 & 29.52 \\
\hline$(3.4,30)$ Rep3 & 308 & 0.9992 & 1.32 & 18.94 & 30.08 & 29.66 \\
\hline$(3.4,40)$ Rep1 & 62 & 0.9996 & 1.40 & 17.86 & 30.11 & 30.29 \\
\hline$(3.4,40)$ Rep2 & 63 & 0.9997 & 2.57 & 9.73 & 30.05 & 32.33 \\
\hline$(3.4,40)$ Rep3 & 82 & 0.9997 & 3.41 & 7.33 & 30.09 & 34.94 \\
\hline$(5.1,30)$ Rep1 & 90 & 0.9989 & 1.09 & 22.94 & 30.21 & 28.94 \\
\hline$(5.1,30)$ Rep2 & 90 & 0.9989 & 0.21 & 119.1 & 30.29 & 30.91 \\
\hline$(5.1,30)$ Rep3 & 90 & 0.9990 & 0.78 & 32.05 & 30.29 & 29.53 \\
\hline$(5.1,40)$ Rep1 & 23 & 0.9998 & 0.39 & 64.10 & 30.43 & 30.60 \\
\hline$(5.1,40)$ Rep2 & 23 & 0.9997 & 0.60 & 41.67 & 29.97 & 29.31 \\
\hline$(5.1,40)$ Rep3 & 21 & 0.9996 & 1.47 & 17.01 & 30.36 & 31.20 \\
\hline
\end{tabular}

${ }^{1}$ Data points $=$ number of data measured for storage modulus $\left(\mathrm{G}^{\prime}\right)$ until $30 \mathrm{~Pa} ; \mathrm{R}^{2}=$ determination coefficient for linear regressions between measured and predicted $\mathrm{G}^{\prime}$ from 5 to $60 \mathrm{~Pa}$; $\mathrm{SEP}=$ standard error of prediction for $\mathrm{G}^{\prime}$ between 5 to $60 \mathrm{~Pa}$; $\mathrm{RER}=$ range error ratio.

${ }^{2}$ Three replicates (Rep) at 2 protein levels $(3.4$ and $5.1 \%)$ and 2 coagulation temperatures $\left(30\right.$ and $\left.40^{\circ} \mathrm{C}\right)$.

${ }^{3}$ Measured and predicted $\mathrm{G}^{\prime}$ values nearest to $\mathrm{G}^{\prime}=30 \mathrm{~Pa}$, respectively.

a coefficient of variation of $5.0 \%$. From our results, models at specific conditions were calibrated and validated successfully. Thus, the results have shown that, for industrial implementation, the model would need to be calibrated for specific conditions of coagulation temperature or milk protein content. In many cheese industries, milk protein level is typically standardized and in all, the coagulation process is carried out at a constant temperature. As a result, once the working conditions for protein and temperature are stablished at a specific cheese manufacturing plant, the calibration process will be consistent, allowing an accurate prediction of the elastic modulus of the gel from the LB ratio and equation [5]. Nevertheless, if significant variations of protein content or temperature were expected at a cheese manufacturing plant, the calibration process would require accounting for variations of those 2 factors through incorporating either protein or temperature terms into the equation. Further calibration efforts at real industrial conditions are, thus, warranted to implement this promising optical, inline prediction model to estimate the elastic modulus of coagulating milk. In Figure 4, the results of 2 of the validations are graphically presented.
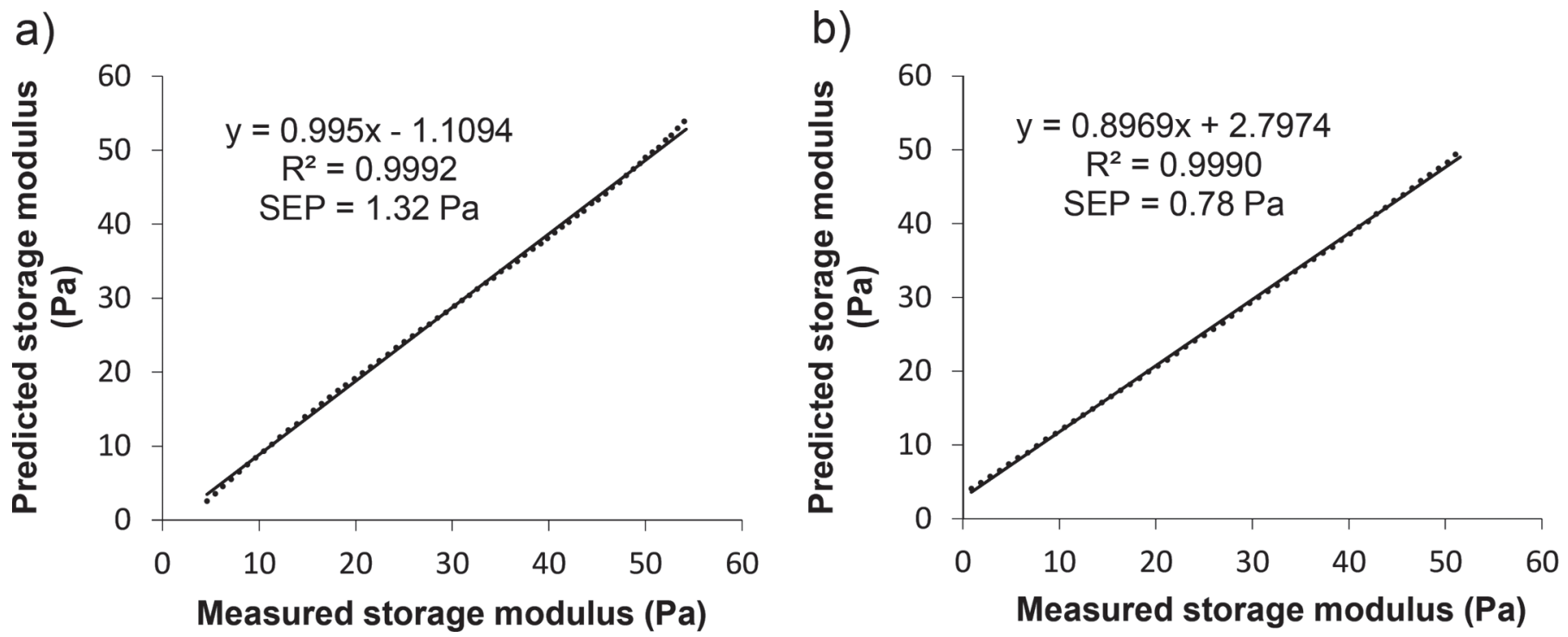

Figure 4. Validation of the model to predict the storage modulus using light backscatter ratio: (a) $3.4 \%$ protein at $30^{\circ} \mathrm{C}$ and (b) $5.1 \%$ protein and $30^{\circ} \mathrm{C}$. SEP $=$ standard error of prediction. 


\section{CONCLUSIONS}

Inline estimation of curd-firming values (the storage modulus) can be successfully achieved in coagulating milk using a nondestructive optical sensor from the increase in $R$ generated in real time from the optical response. The proposed method may allow initiating the curd cutting at an optimum selected firmness according to the type of cheese going to be made; however, the results showed that, for industrial implementation, the model would need to be calibrated for specific conditions of coagulation temperature or milk protein content. In many cheese industries, the milk protein level is standardized, and the coagulation process is always carried out at a specific temperature; thus, once the working conditions for protein and temperature are established at a specific cheese manufacturing plant, the calibration process will not be a problem.

\section{ACKNOWLEDGMENTS}

This study was co-funded by the European Regional Development Fund. The authors thank the Animal and Food Science Department, Universidad Autónoma de Barcelona. During this research, O. Arango was supported by a Formació de personal investigador (FI)-Direcció General de Recerca (DGR) grant from Generalitat of Catalunya (Catalonia, Spain) and by Universidad de Nariño (Pasto, Colombia).

\section{REFERENCES}

Abdelgawad, A. R., B. Guamis, and M. Castillo. 2014. Using a fiber optic sensor for cutting time prediction in cheese manufacture from a mixture of cow, sheep and goat milk. J. Food Eng. 125:157-168.

Arango, O., M. Castillo, and A. J. Trujillo. 2013. Influence of fat replacement by inulin on rheological properties, kinetics of rennet milk coagulation and syneresis of milk gels. J. Dairy Sci. 96:19841996. https://doi.org/10.3168/jds.2012-5763.

Bittante, G., M. Penasa, and A. Cecchinato. 2012. Invited review: Genetics and modeling of milk coagulation properties. J. Dairy Sci. 95:6843-6870. https://doi.org/10.3168/jds.2012-5507.

Carlson, A., C. G. Hill, and N. E. Olson. 1987. Kinetics of milk coagulation: III. Mathematical modelling of the kinetics of curd formation following enzymatic hydrolysis of K-casein-parameter estimation. Biotechnol. Bioeng. 29:601-611. https://doi.org/10.1002/bit .260290509 .

Castillo, M. (2006a). Cutting time prediction methods in cheese making. Pages 1-7 in Encyclopedia of Agricultural, Food, and Biological Engineering. Vol. 1. D. Heldman, ed. Taylor \& Francis Group, Boca Raton, FL.

Castillo, M., J. A. Lucey, and F. A. Payne. 2006b. The effect of temperature and inoculum concentration on rheological and light scatter properties of milk coagulated by a combination of bacterial fermentation and chymosin. Cottage cheese-type gels. Int. Dairy J. 16:131-146. https://doi.org/10.1016/j.idairyj.2005.02.005.

Castillo, M., F. A. Payne, C. L. Hicks, J. S. Laencina, and M. B. López. 2003a. Effect of protein and temperature on cutting time prediction in goats' milk using an optical reflectance sensor. J. Dairy Res. 70:205-215. https://doi.org/10.1017/S0022029903006113.
Castillo, M. Z., F. A. Payne, C. L. Hicks, J. S. Laencina, and M. B. Lopez. 2003b. Modeling casein aggregation and curd firming in goats' milk from backscatter of infrared light. J. Dairy Res. 70:335-348. https://doi.org/10.1017/S0022029903006356.

Castillo, M., F. A. Payne, C. L. Hicks, and M. B. Lopez. 2000. Predicting cutting and clotting time of coagulating goats' milk using diffuse reflectance: Effect of $\mathrm{pH}$, temperature and enzyme concentration. Int. Dairy J. 10:551-562. https://doi.org/10.1016/S0958 -6946(00)00086-8.

Clark, A. H., and E. H. Amici. 2003. The formation and properties of biopolymer gels. Pages 35-48 in Food Colloids and Materials. E. Dickinson, T. and Van Vliet, ed. Royal Society of Chemistry, Cambridge, UK.

Cosgrove, N. 2000. Design and development of an ultrasonic measuring system to monitor milk coagulation. MSc Thesis. National University of Ireland, Dublin, Ireland.

Dal Zotto, R., M. de Marchi, A. Cecchinato, M. Penasa, M. Cassandro, P. Carnier, L. Gallo, and G. Bittante. 2008. Reproducibility and repeatability of measures of milk coagulation properties and predictive ability of mid-infrared reflectance spectroscopy. J. Dairy Sci. 91:4103-4112. https://doi.org/10.3168/jds.2007-0772.

Douillard, R. 1973. Rheological analysis of curd formation. J. Texture Stud. 4:158-165.

Everard, C. D., D. J. O'Callaghan, M. J. Mateo, C. P. O'Donnell, M. Castillo, and F. A. Payne. 2008. Effects of cutting intensity and stirring speed on syneresis and curd losses during cheese manufacture. J. Dairy Sci. 91:2575-2582. https://doi.org/10.3168/jds $.2007-0628$.

Fagan, C. C., M. Castillo, F. A. Payne, C. P. O'Donnell, and D. J. O'Callaghan. 2007. Effect of cutting time, temperature and calcium on curd moisture, whey fat loses and curd yield by response surface methodology. J. Dairy Sci. 90:4499-4512. https://doi.org/ 10.3168/jds.2007-0329.

Fagan, C. C., C. P. O'Donnell, D. J. O'Callaghan, M. Castillo, and F. A. Payne. 2009. Visible-near infrared spectroscopy sensor for predicting curd and whey composition during cheese processing. Sens. Instrum. Food Qual. Saf. 3:62-69. https://doi.org/10.1007/ s11694-009-9073-5.

Frederiksen, P. D., K. K. Andersen, M. Hammersh øj, H. D. Poulsen, J. Sørensen, M. Bakman, K. B. Qvist, and L. B. Larsen. 2011. Composition and effect of blending of noncoagulating, poorly coagulating, and well-coagulating bovine milk from individual Danish Holstein cows. J. Dairy Sci. 94:4787-4799. https://doi.org/10 $.3168 /$ jds.2011-4343.

Guinee, T. P., C. Gorry, D. J. O'callaghan, B. O'kennedy, N. O'brien, and A. Fenelon. 1997. The effects of composition and some processing treatments on the rennet coagulation properties of milk. Int. J. Dairy Technol. 50:99-106. https://doi.org/10.1111/j.1471 -0307.1997.tb01747.x.

Hallén, E., T. Allmere, J. Näslund, A. Andrén, and A. Lundén. 2007. Effect of genetic polymorphism of milk proteins on rheology of chymosin-induced milk gels. Int. Dairy J. 17:791-799. https://doi .org/10.1016/j.idairyj.2006.09.011.

Hemar, Y., H. Singh, and D. S. Horne. 2004. Determination of early stages of rennet induced aggregation of casein micelles by diffusing wave spectroscopy and rheological measurements. Curr. Appl. Phys. 4:362-365. https://doi.org/10.1016/j.cap.2003.11.049.

Hori, T. 1985. Objective measurements of the process of curd formation during rennet treatment of milks by the hot-wire method. J. Food Sci. 50:911-917. https://doi.org/10.1111/j.1365-2621.1985 .tb12978.x.

Horne, D. S., and J. M. Banks. 2004. Rennet-induced coagulation of milk. Pages 47-70 in Cheese Chemistry, Physics and Microbiology, Volume 1. General Aspects. 3rd ed. P. F. Fox, P. L. H. McSweeney, T. M. Cogan, and T. P. Guinee, ed. Elsevier Academic Press, New York, NY

IDF. 2002. Milk and milk products. Determination of nitrogen content. Routine method using combustion according to the Dumas principle. IDF Standard 185. International Dairy Federation, Brussels, Belgium. 
Jakob, M., D. Jaros, and H. Rohm. 2011. Recent advances in milk clotting enzymes. Int. J. Dairy Technol. 64:14-33. https://doi.org/ 10.1111/j.1471-0307.2010.00633.x.

Klandar, A. H., A. Lagaude, and D. Chevalier-Lucia. 2007. Assessment of the rennet coagulation of skim milk: A comparison of methods. Int. Dairy J. 17:1151-1160. https://doi.org/10.1016/j idairyj.2007.03.005

Koc, A., and B. Ozer. 2008. Nondestructive monitoring of renetted whole milk during cheese manufacturing. Food Res. Int. 41:745750. https://doi.org/10.1016/j.foodres.2008.05.008.

Kübarsepp, I., M. Henno, O. Kart, and T. Tupasela. 2005. A comparison of the methods for determination of the rennet coagulation properties of milk. Acta Agric. Scand. A Anim. Sci. 55:145-148. https://doi.org/10.1080/09064700500453377.

Nicolau, N., M. Castillo, M. Buffa, D. J. O'Callaghan, and B. Guamis. 2011. Light scatter estimation of clotting and cutting time in sheep cheese manufacture. International Conference on Engineering and Food, ICEF 11. Athens, Greece.

O'Callaghan, D. J., E. P. Mulholland, A. P. Duffy, C. P. O'Donnell, and F. A. Payne. 2001. Evaluation of hot wire and optical sensors for online monitoring of curd firmness during milk coagulation. Ir. J. Agric. Food Res. 40:227-238. http://www.jstor.org/stable/ 25562438.

Passos, E. F., P. S. Monteiro, R. C. Oliveira, J. G. O. Martins, H. G. Alves, and S. C. C. Brandao. 1999. Predicting the cutting time of coagulating milk for cheese production using a heated thermistor. J. Food Sci. 64:879-882. https://doi.org/10.1111/j.1365-2621.1999 .tb15932.x.

Payne, F. A., C. L. Hicks, and P. S. Shen. 1993. Predicting optimal cutting time of coagulating milk using diffuse reflectance. J. Dairy Sci. 76:48-61. https://doi.org/10.3168/jds.S0022-0302(93)77322-1.

Payne, F. A., S. Madangopal, C. L. Hicks, and S. A. Shearer. 1990. Fiber optic milk coagulation sensor for cut-time detection. Page
173 in Food Processing Automation Conference, Publication 0290. American Society of Agricultural Engineers, St. Joseph, MI.

Scott Blair, G. W., and J. Burnett. 1958. Physical changes in milk caused by the action of rennet. 1. Description of apparatus for measuring rigidity moduli and internal viscosities, tests of reliability and some observations on syneresis. J. Dairy Res. 25:297-303. https://doi.org/10.1017/S0022029900009286.

Tabayehnejad, N., M. Castillo, and F. A. Payne. 2012. Comparison of total milk-clotting activity measurement precision using the Berridge clotting time method and a proposed optical method. J. Food Eng. 108:549-556. https://doi.org/10.1016/j.jfoodeng.2011 .09 .009 .

Taifi, N., F. Bakkali, B. Faiz, A. Moudden, G. Maze, and D. Decultot. 2006. Characterization of the syneresis and the firmness of the milk gel using an ultrasonic technique. Meas. Sci. Technol. 17:281-287. https://doi.org/10.1088/0957-0233/17/2/008.

Tokita, M., R. Kikichi, R. Niki, and S. Arima. 1982. Dynamic viscoelastic studies on the mechanism of milk clotting process. Biorheology 19:209-219.

Tuszynski, W. B. 1971. A kinetic model of the clotting of casein by rennet. J. Dairy Res. 38:113-125. https://doi.org/10.1017/ S0022029900019233.

van Hooydonk, A. C., and G. van den Berg. 1988. Control and Determination of the Curd-Setting During Cheesemaking. International Dairy Federation, Brussels, Belgium.

Williams, P., and K. Norris. 1987. Near-Infrared Technology in the Agricultural and Food Industries, 2nd ed. P. Williams and K. Norris, ed. AACC, St. Paul, MN.

Zoon, P., T. van Vliet, and P. Walstra. 1988. Rheological properties of rennet-induced skim milk gels. 2. Effect of temperature. Neth. Milk Dairy J. 42:271-294. 